2

\title{
Bioprecipitation: A feedback cycle linking Earth history, ecosystem dynamics and land use through biological ice nucleators in the atmosphere
}

\author{
Cindy E. Morris ${ }^{1,2}$, Franz Conen ${ }^{3}$, J. Alex Huffman ${ }^{4}$, Vaughan Phillips ${ }^{5}$, Ulrich Pöschl ${ }^{6}$, \\ David C. Sands ${ }^{2}$
}

${ }^{1}$ INRA, UR0407 Pathologie Végétale, F-84143 Montfavet cedex, France

${ }^{2}$ Dept. Plant Sciences and Plant Pathology, 119 Plant Bioscience Bldg., Montana State University, Bozeman, MT 59717-3150, USA

${ }^{3}$ Department of Environmental Sciences, University of Basel, 4056 Basel, Switzerland

${ }^{4}$ University of Denver, Department of Chemistry and Biochemistry, Denver, CO, 80208, USA

${ }^{5}$ Department of Physical Geography and Ecosystem Science, Lund University, Solvegatan 12, 22362 Lund, Sweden

${ }^{6}$ Max Planck Institute for Chemistry, Biogeochemistry and Multiphase Chemistry Departments, 55128 Mainz, Germany

\section{*Corresponding author:} tel: +33 (0)4 327228 41, fax: +33 (0)4 32722842 cindy.morris@avignon.inra.fr

Keywords: biological ice nucleation, cloud physics, ice multiplication, aerobiology, Pseudomonas syringae, rainfall

Type of paper: Opinion 
Version définitive du manuscrit publié dans / Final version of the manuscript published in Global Change Biology, 2014, 20 (2), 341-51. DOI : 10.1111/gcb.12447. The original publication is available at Wiley Online library.

\section{Abstract:}

25 Landscapes influence precipitation via the water vapor and energy fluxes they generate.

26 Biologically active landscapes also generate aerosols containing microorganisms, some being

27 capable of catalyzing ice formation and crystal growth in clouds at temperatures near $0^{\circ} \mathrm{C}$. The

28 resulting precipitation is beneficial for the growth of plants and microorganisms. Mounting

29 evidence from observations and numerical simulations support the plausibility of a

30 bioprecipitation feedback cycle involving vegetated landscapes and the microorganisms they

31 host. Furthermore, the evolutionary history of ice nucleation active bacteria such as

32 Pseudomonas syringae supports that they have been part of this process on geological time scales

33 since the emergence of land plants. Elucidation of bioprecipitation feedbacks involving

34 landscapes and their microflora could contribute to appraising the impact that modified

35 landscapes have on regional weather and biodiversity, and to avoiding inadvertent, negative

36 consequences of landscape management. 

library.

Microorganisms have long played important roles in the Earth system. For example, the most important change in the history of Earth's climate, and the most significant for life on our planet, was the rise in atmospheric $\mathrm{O}_{2}$ concentration from $2 \%$ about 2.3 billion years ago (Gya) to the current concentration of $20 \%$ (Kasting \& Siefert, 2002), caused primarily by microorganisms.

They are also currently responsible for about $70 \%$ of the greenhouse gas methane released into the atmosphere (Conrad, 2009), and for production of nitrogen oxides and of the precursor of dimethlysulfide, a major source of atmospheric sulfur (Bates et al., 1992). In light of these and other roles in Earth system process, the American Academy of Microbiology recently and justifiably pointed out the need to integrate microbiology more closely with the study of climate processes (Reid, 2011). Their report called for enhanced interdisciplinary collaboration on a range of biogeochemical processes, yet it neglected processes whereby microorganisms influence climate (cloud and rainfall patterns in particular) via their impact on atmospheric chemistry and physics.

Over the past decade interest has grown in the so-called bioprecipitation hypothesis: a feedback cycle whereby land plants generate small airborne particles (aerosols) containing plant-associated microorganisms that influence formation and evolution of clouds via their ice nucleation activity, leading to precipitation that in turn is beneficial for plant and microbial growth (Sands et al., 1982) (Figure 1.). The renewed interest in this hypothesis has been ignited, in part, by the surging need for more precise quantification of cloud evolution for models of global climate change and by recurring droughts and desertification. Part of this renewed effort has been to assemble the evidence that ice nucleation active (INA) microorganisms indeed affect the microphysical processes in clouds leading to rainfall (Szyrmer \& Zawadzki, 1997; Möhler et al., 2007; DeMott \& Prenni, 2010; Morris et al., 2011; Murray et al., 2012). The effect of 

library.

microorganisms on the microphysical processes in clouds is one essential component of

bioprecipitation. But there has been little effort to illustrate how it is part of greater Earth system processes. In this paper we go beyond previous reviews of microbial ice nucleation by bringing together current information supporting that microbial-induced ice nucleation in clouds is directly linked to a feedback cycle with plants, and by illustrating how this cycle benefits from auxiliary processes that reinforce ice nucleation activity in microorganisms. As landscapes are modified by human activities, and as the ranges of habitats of plants change with the changing climate of the Earth, feedback cycles could lead to unexpected consequences. Elucidation of precipitation feedbacks involving landscapes and their microflora could contribute to appraising the impact that modified landscapes have on regional weather and biodiversity, and to avoiding inadvertent, negative consequences of landscape management. Therefore, we believe that concerted effort for such elucidation is needed.

\section{The essential components of a bioprecipitation cycle}

Knowledge of well-known environmental processes led Sands and colleagues (Sands et al., 1982) to propose the bioprecipitation cycle over 30 years ago. Recently, there have been reports of additional phenomena associated with the two basic components of this feedback cycle that add credibility to its existence.

Component 1: Plants emit water vapor and release microorganisms into the atmosphere. The water vapor emitted from plants is essential for cloud formation and ice nuclei are critical for rainfall. Among the microorganisms released are INA strains of various species of bacteria and fungi (Morris et al., 2004; Murray et al., 2012), and these microorganisms can be transported to the altitude of clouds as aerosols. A wide range of microorganisms has been observed directly in 
Version définitive du manuscrit publié dans / Final version of the manuscript published in Global Change Biology, 2014, 20 (2), 341-51. DOI : 10.1111/gcb.12447. The original publication is available at Wiley Online library.

cloud water, including bacteria and fungi known to be INA (Amato et al., 2007; Joly et al., 2013). Laboratory studies have shown that the harsh conditions endured during ascent and residence in the atmosphere are not detrimental to bacterial ice nucleation activity (Attard et al., 2012). The potential efficiency of microbial ice nuclei in this role has been the subject of the numerous reviews indicated above.

Component 2: Rainfall provides water for growth of plants and for multiplication of microorganisms. The latter benefit from increased plant mass and directly from the availability of water. Plant water vapor and microorganisms can then feed back into the first component of the cycle. The idea of the bioprecipitation cycle arose from the obvious beneficial impact of rain on plant growth and the subsequent enhanced growth of microorganisms due to the increased availability of plant tissue. Furthermore, it is well-known that wet conditions favor nearly all diseases of leaf tissue caused by fungi or bacteria (with the exception of the powdery mildews that proliferate in dry weather) including those caused by INA microorganisms that are also plant pathogens (bacteria and rust fungi, for example) (Agrios, 2005). More specifically, studies of molecular mechanisms of plant disease resistance have revealed, for the case of the INA bacterium Pseudomonas syringae in particular, that plants interfere with the growth of bacterial pathogens by restricting their access to water at the cellular level (Freeman \& Beattie, 2009), further illustrating the critical role of water limitation in the multiplication of plant-associated bacteria. As a corollary to these phenomena, heavy rainfalls $(\geq 20 \mathrm{~mm})$ result in thousand-fold increases in population sizes of $P$. syringae on leaves within 48 hours, and these increased densities can persist for weeks before declining (Hirano et al., 1996). It is reasonable to assume that as population sizes of microorganisms on leaves increase, the emission of microorganisms 
109 from these leaves increases. However, there has not been a formal demonstration of this

110 phenomenon, mostly due to the paucity of studies of microbial flux in the atmosphere (Morris et

$111 a l ., 2013 a)$. Nevertheless, in one of the few studies of microbial flux, upward flux over crops was

112 the highest over the crops having the most dense microbial populations on their leaves

113 (Lindemann et al., 1982). Overall, plant quality affects the abundance of biological ice nuclei in

114 the atmosphere, with the greatest concentrations being observed over agricultural land than over

115 suburban land or forests (Bowers et al., 2011). Finally, rainfall is followed by enrichment of ice

116 nuclei in the atmosphere (Bigg, 1958; Constantinidou et al., 1990; Huffman et al., 2013; Prenni

117 et al., 2013; Tobo et al,. 2013) some of which are microbial.

118 The framework for the bioprecipitation cycle has been largely inspired by knowledge of the 119 emission of ice nucleation active microorganisms such as $P$. syringae and rust fungi from plants 120 and their transport through the atmosphere and clouds. Nevertheless, this cycle is pertinent for 121 any biological INA particle whose abundance increases as a feedback response to the 122 precipitation that it initiated. Therefore, INA particles implicated in a bioprecipitation cycle 123 would have to multiply by reproduction at least during some part of the cycle, although they 124 could be functionally incapable of reproduction by the time in the cycle that emission or 125 glaciation occurred. Many different types of biological ice nuclei have been detected in the 126 atmosphere but, to date, only a few of them have been specifically linked to the full set of 127 processes involved in the bioprecipitation cycle (Figure 1).

\section{The impact of biological ice nuclei on cold clouds - a contentious issue}

129 The real impact of INA microorganisms on cloud microphysics and subsequent precipitation has

130 been a subject of contention. There is generally agreement that the atmospheric processes

131 leading to interaction of ice nuclei and super cooled cloud droplets could set INA 
Version définitive du manuscrit publié dans / Final version of the manuscript published in Global Change Biology, 2014, 20 (2), 341-51. DOI : 10.1111/gcb.12447. The original publication is available at Wiley Online library.

132 microorganisms into the appropriate context to catalyze freezing, and this has been substantiated

133 by direct observation of such microorganisms in clouds as indicated above. However, the crux of

134 the debate is whether there are sufficient numbers of biological ice nuclei in clouds to set off a

135 process that renders measurable precipitation.

136 There are two main pathways by which precipitation forms in natural clouds. The "warm rain

137 process" involves collisions between cloud droplets of differing sizes and fall speeds, resulting in

138 coalescence. The warm rain process tends to dominate precipitation production in deep

139 convective clouds with warm bases and rapid ascent $>1 \mathrm{~m} / \mathrm{s}$ aloft (Phillips et al., 2001, 2005).

140 The "ice crystal process" involves nucleation of ice followed by vapor growth of crystals, riming

141 of supercooled droplets and aggregation of ice. This type of precipitation is sensitive to active

142 concentrations of ice nuclei (Phillips et al., 2003). Horizontally extensive stratiform (non-

143 convective) clouds that contain ice and are mixed-phase (liquid and ice co-existing), such as

144 frontal nimbostratus clouds, can generate precipitation by this ice-crystal process. In the present-

145 day climate, mixed-phase nimbostratus clouds (and thus the cold-rain process) are more common

146 at mid- and high latitudes than in the tropics and sub-tropics (Rossow \& Schiffer, 1999; Hahn et

147 al., 2001). Their slow ascent $(<1 \mathrm{~m} / \mathrm{s})$ and longevity (lifetimes of many hours) allow ice crystals

148 to fall, to grow by vapor deposition and consequently to become precipitation in the form of ice

149 that may melt.

150 When the cloud top is warmer than about $-37^{\circ} \mathrm{C}$, nimbostratus precipitation is predicted to be

151 boosted by higher total concentrations of all active ice nuclei - biological, mineral or others

152 (Phillips et al., 2003). It is under such conditions that INA microorganisms could be involved in

153 the freezing process and hence in precipitation. A role for INA microorganisms is especially

154 expected for glaciated clouds with tops too warm for INA dust to be prolific (warmer than about 
Version définitive du manuscrit publié dans / Final version of the manuscript published in Global Change Biology, 2014, 20 (2), 341-51. DOI : 10.1111/gcb.12447. The original publication is available at Wiley Online library.

155

156

157

158

159

160

161

162

163

164

165

166

167

168

169

170

171

172

173

174

175

176

177

-15 to $-20{ }^{\circ} \mathrm{C}$ ). For clouds with colder tops, the few estimates available suggest that the

abundance of active bacterial ice nuclei (those active at warmer than ca. $-10^{\circ} \mathrm{C}$ ) in the remote

free troposphere over continental regions (Bowers et al., 2009) is typically at least two orders of

magnitude lower than that of mineral or other non-biological ice nuclei active at much colder

temperatures (colder than $-20^{\circ} \mathrm{C}$ ) (DeMott et al., 2003) and might be insufficient to influence

precipitation. However, INA microorganisms can benefit from a process of ice multiplication

that is restricted to a very specific temperature range, if their primary ice can grow to become ice

precipitation aloft. Between $-3^{\circ}$ and $-8^{\circ} \mathrm{C}$, the number of ice particles in clouds can be amplified

by the Hallett-Mossop (H-M) process of ice multiplication (Hallett \& Mossop, 1974; Harris-

Hobbs \& Cooper, 1987), which involves rime-splintering of ice precipitation leading to ice

concentrations that are several orders of magnitude greater than what would be expected due to

primary ice nucleation alone (Bower et al., 1996). Indeed, such impacts from biological ice

nuclei on the H-M process have been simulated (Phillips et al., 2009). Virtually none of the non-

biological ice nuclei naturally present in the atmosphere, such as mineral dust (active when colder

than -10 to $-20^{\circ} \mathrm{C}$ ) (Ansmann et al., 2008; DeMott et al., 2011) or soot (active when colder than

$-20^{\circ} \mathrm{C}$ ) (DeMott, 1990), can prolifically catalyze ice formation in the temperature range of the H-

M process (Hallett \& Mossop, 1974), whereas INA bacteria clearly catalyze ice formation in this

temperature range and under conditions simulating clouds (Möhler et al., 2008).

One of the first global modeling studies of biological ice nuclei predicted that their contribution

to the global average ice nucleation rate is very small $\left(10^{-5}-0.6 \%\right)$ (Hoose et al., 2010).

However, this study doesn't take ice multiplication effects such as the H-M effect or rime

splintering into account, and there is much uncertainty about how to simulate biological ice

nuclei. This global study was based on properties of a specific strain of $P$. syringae recently

1 
Version définitive du manuscrit publié dans / Final version of the manuscript published in Global Change Biology, 2014, 20 (2), 341-51. DOI : 10.1111/gcb.12447. The original publication is available at Wiley Online library.

178

179

180

181

182

183

184

185

186

187

188

189

190

191

192

193

194

195

196

197

198

199

200

shown to have IN efficiencies much lower (by at least about 3 orders of magnitude) than many other strains of this bacterium (Murray et al., 2012). Moreover, a separate empirical

parameterization of ice nucleation by aerosol species predicts that $3-6 \%$ of all active ice nuclei at $-30^{\circ} \mathrm{C}$ are biological in the continental background troposphere based on observations of very

large samples of many strains of naturally-occurring P. syringae (Phillips et al., 2008, 2013).

This parameterization was validated against coincident field measurements of active biological ice nuclei and bio-aerosol particles in Colorado (Phillips et al., 2013). At least over certain continental regions such as the tropical rainforest basin in the Amazon, the formation of ice and precipitation in deep stratiform clouds and convective clouds with cold bases and tops warmer than about -15 to $-20{ }^{\circ} \mathrm{C}$ (ice nuclei from dust have little activity at temperatures warmer than this), and the glaciation of deep convective clouds with warm bases, are all likely triggered by biological particles. In such clouds, biological ice nuclei are present and in some cases may prevail in the overall initiation of primary ice ( Prenni et al., 2009; Pöschl et al., 2010).

The growing pool of data on abundance of microbial ice nuclei in the atmosphere portends the emergence of more studies illustrating regional impacts of these ice nuclei on precipitation.

(Phillips et al., 2013; Prenni et al., 2013). However, there will be further points of contention to resolve. First, not all particles carrying surfaces of biological origin and capable of catalyzing ice formation at warm temperatures $\left(>-10^{\circ} \mathrm{C}\right)$ are microorganisms launched from plant surfaces. Another form of biological IN includes decomposed organisms, or parts thereof, attached to soil minerals (Conen et al., 2011; O’Sullivan et al., 2013). Soil organic matter typically has a turnover time of decades to centuries. Abundance and IN activity associated with it are unlikely affected by precipitation events in the short term and therefore unlikely to play a role in bioprecipitation as we understand it. Second, the presence of INA microorganisms in clouds is proof that they are 
Version définitive du manuscrit publié dans / Final version of the manuscript published in Global Change Biology, 2014, 20 (2), 341-51. DOI : 10.1111/gcb.12447. The original publication is available at Wiley Online library.

201 transported up to the altitude of clouds (Amato et al., 2007; Joly et al., 2013). But there are few

202 data available about how this happens - about the conditions that are favorable for this transport

203 and about real measured rates of transport from different sources. Furthermore, some of the

204 available data seem to contradict each other. In the only reported direct measurement of flux of

205 INA microorganisms into the atmosphere, they ascended at 72 cells $\mathrm{m}^{-2} \mathrm{~min}^{-1}$. The bacterium $P$.

206 syringae contributed $75 \%$ of this INA aerosol (Lindemann et al., 1982). Under these same

207 conditions, INA $P$. syringae was found in aerosols at canopy height at concentrations of about 6

208 cells $\mathrm{m}^{-3}$ in a snap bean field having on average $2.7 \times 10^{6}$ INA $P$. syringae per gram of leaf. This

209 microbial aerosol concentration is at the limit of sensitivity of sampling and detection methods

210 available in aerobiology and illustrates why there have been such few reports of successful

211 detection of $P$. syringae or other INA microorganisms in dry aerosols. Under conditions where

212 INA Pseudomonas spp. were present on plant canopies, Garcia and colleagues failed to detect

213 these bacteria in most samples of aerosols collected downwind of the suspected source fields and

214 were successful only during combine harvesting of the fields (Garcia et al., 2012). Although the

215 authors were surprised by this result, it can be explained by the differences in detection

216 thresholds of the technique they used compared to that of Lindemann and colleagues. Garcia and

217 colleagues used a direct molecular detection method based on polymerase chain reaction (PCR)

218 amplification of the gene for ice nucleation activity (the ina or the ice gene) in Pseudomonas spp.

219 The detection threshold of this technique, according to the reported methods, was 0.1 copies of

220 the targeted gene per liter of air. It can be assumed that cells of Pseudomonas spp. carry 1 copy

221 of the ina or ice gene per cell, therefore this threshold is equivalent to 0.1 cells $\mathrm{L}^{-1}$. In contrast,

222 using microbiological culture media, Lindemann and colleagues could detect as few as 0.001

223 bacterial cells $\mathrm{L}^{-1}$. When Garia and colleagues detected INA bacteria in air samples during

224 combine harvesting of the agricultural fields at their experimental site, a context where high 
Version définitive du manuscrit publié dans / Final version of the manuscript published in Global Change Biology, 2014, 20 (2), 341-51. DOI : 10.1111/gcb.12447. The original publication is available at Wiley Online library.

225 quantities of aerosols are generated, the concentrations were about 19 cells $\mathrm{L}^{-1}$. This represented

2262 orders of magnitude above their own detection limit and 4 orders of magnitude more than the

227 concentrations observed by Lindemann and colleagues during the crop growth season. Hence, it

228 is likely that atmospheric concentrations of INA bacteria were below the limits of detection for

229 most of the sampling times in the study of Garcia and colleagues thereby giving the impression

230 that they were not present as aerosols. The sensitivity of detection methods for INA

231 microorganisms in the atmosphere is not the only problem that will complicate the debate about

232 the role of these microorganisms in precipitation. As described in previous work (Morris et al.,

233 2012) thermal plumes can have an important role in the upward flux of microorganisms from

234 plant surfaces. These plumes are "packages" of air that can uplift the associated aerosols without

235 marked dilution and they are not uniformly distributed across a landscape. The results of such a

236 phenomenon have in fact been observed in the dissemination of fungi (Hirst et al., 1967). The

237 resulting uneven and aggregated distribution of aerosols suggests that air samples might not

238 necessarily reflect the spatial and temporal variability of atmospheric microbial concentrations.

Favorable environmental contexts for the emergence and maintenance of a bioprecipitation cycle

Atmospheric circulation of heat and water vapor and the distribution of clouds have changed over Earth's history. The dramatic changes leading to modern atmospheric circulation began about 100 million years ago with the break-up of Pangea during the Cretaceous period. Poleward shifts of land masses and the uprising of mountains contributed to ascent and adiabatic cooling of rising air over the newly created continents (DeConto, 2008) thereby leading to sub-zero temperatures in clouds at mid and high latitudes over these continents in contrast to the arid desert that had 
Version définitive du manuscrit publié dans / Final version of the manuscript published in Global Change Biology, 2014, 20 (2), 341-51. DOI : 10.1111/gcb.12447. The original publication is available at Wiley Online library.

248

249

250

251

252

253

254

255

256

257

258

259

260

261

262

263

264

265

266

267

268

269

270

covered much of the interior of Pangea previously. The changing climatic conditions were

accompanied by an expansion across mid- and high latitudes of terrestrial angiosperms and, in

particular, temperate forests (Zhou et al., 2012). This set in place conditions that could have been

exploited by plant-associated INA microorganisms. Data on the evolutionary history of the gene

conferring ice nucleation activity in bacteria and of the major class of bacteria that possess this

gene, the $\gamma$-Proteobacteria, suggest that as of the Cretaceous period of Earth's history all of the

fundamental conditions were in place for INA $\gamma$-Proteobacteria to play a role in ice-induced

rainfall.

Although the ability to catalyze the freezing of water above the temperature of spontaneous freezing (ca. $-37^{\circ} \mathrm{C}$ ) (Murray et al., 2010) is a property of various organisms, non-living organic

compounds and minerals (Mossop, 1963; Morris et al., 2004; Murray et al., 2012), the most is

known about this capacity for the class of bacteria called the $\gamma$-Proteobacteria. Strains of these

bacteria catalyze freezing at the warmest temperatures of all the INA materials regularly found in

the environment (Murray et al., 2012). An outer membrane protein orients water molecules into

the cubic form of ice that spontaneously converts to hexagonal ice (Kajava, 1995) in a process

that resembles the recently discovered shift from cubic to hexagonal ice that can occur during the

spontaneous freezing of water in the atmosphere (Murray et al., 2005). The most plausible origin

of the gene for the INA protein in the $\gamma$-Proteobacteria is from a common ancestor of the highly

divergent orders of bacteria in which it has been described: Xanthomonadales, Pseudomonadales,

Enterobacteriales (Wolber, 1993). This allows us to estimate that the gene has been part of the $\gamma$ -

Proteobacteria since sometime between the emergence of this class of bacteria (ca. 1.75 Gya

(Battistuzzi et al., 2004)) and the diversification of some of the youngest genera in this class $(0.5$

Gya (Lerat et al., 2003)). During this part of Earth's history there were significant periods of 
Version définitive du manuscrit publié dans / Final version of the manuscript published in Global Change Biology, 2014, 20 (2), 341-51. DOI : 10.1111/gcb.12447. The original publication is available at Wiley Online library.

271 glaciation (Fig. 2). This provided millions of years of opportunity for the INA protein to interact

272 with freezing water.

273 One of the most intriguing aspects of bacterial ice nucleation activity is its efficiency relative to

274 that of mineral particles or of other biological ice nuclei. INA $\gamma$-Proteobacteria have orders of

275 magnitude more ice active sites per surface area of their cells than fungi or birch pollen or when

276 compared in terms of surface area to inert particulate matter such as ash, dust, soot and other INA

277 minerals (Murray et al., 2012). It is likely that the remarkable ice nucleation activity of these

278 bacteria results from cycles of natural selection during the evolution of the $\gamma$-Proteobacteria. A

279 hallmark of natural selection on a trait is that it causes the trait to be markedly less variable

280 among strains within specific genetic lineages of a population than between different genetic

281 lineages (Nielsen, 2005). Interestingly, INA is not a uniform trait across the $\gamma$-Proteobacteria

282 class or even within the $P$. syringae species complex nor does it seem to be a randomly

283 distributed capacity among the different strains of these groups. Certain genetic lineages of $P$.

284 syringae, for example, clearly have higher frequencies of very efficient INA strains than other

285 lineages (Morris et al., 2010) corroborating the importance of positive natural selection in the

286 evolution of this trait.

287 There are several ways in which catalysis of freezing could have been an advantage for the

288 fitness of bacteria in the $\gamma$-Proteobacteria class. It should be noted that there is no evidence for

289 other functions of the ice nucleation protein beyond being INA (Wolber, 1993) and thus the

290 fitness advantages of freezing would have, in themselves, led to positive natural selection of ice

291 nucleation activity. During their early evolution before the emergence of life on land, the $\gamma$ -

292 Proteobacteria were aquatic organisms. The advantage of INA in aquatic habitats has likely been

293 due to the enhanced survival gained by managing ice formation outside of the cell wall. 

library.

294 Nucleation of ice outside of the cell, whether provoked by an organism itself or induced during

295 procedures of cryoconservation, is an effective method of protecting cells during freezing events

296 in the ambient environment (Fahy, 1995; Zachariassen \& Kristiansen, 2000). In aquatic habitats,

297 freezing might also be a means to increase access to nutrients. It has been shown that microbial

298 INA is responsible for the formation of frazil ice in aggregates of diatoms and bacteria. This is

299 thought to benefit the bacteria associated with the aggregates because the frazil ice floats to the

300 surface where the diatoms have greater access to light thereby producing more photosynthates

301 that are food for the associated bacteria (D'Souza et al., 2013). Presently, aquatic milieus are still

302 habitats for INA bacteria. INA Pseudomonas spp. have been found in salt water (Fall \& Schnell,

303 1985) and in a supragalcial stream in Antarctica (Foreman et al., 2013), and INA P. syringae are

304 abundant in fresh water (Morris et al., 2008, 2010). When INA bacteria became associated with

305 land plants, one likely impact of ice nucleation activity has been the gain in fitness from

306 nutrients released from leaf tissue damaged during ice formation (Wolber, 1993).

307 It has been proposed that, by inducing precipitation, INA microorganisms also procure a gain in

308 fitness that leads to positive selection of ice nucleation activity (Wolber, 1993; Morris et al.,

309 2010, 2012). This idea is supported by evidence from ecological studies of $P$. syringae, one of

310 the most environmentally predominant INA microbial species. However, it should be kept in

311 mind that precipitation is one of several processes of natural selection that have honed the ice

312 nucleation activity of this species. The percent of cells of the entire $P$. syringae global population

313 that actually attains cloud height is unknown and might be very small. Hence, precipitation alone

314 has probably not been the main driver in the evolution of ice nucleation activity. Nevertheless,

315 the enrichment of INA $P$. syringae in rain and snowfall compared to its population in clouds 
Version définitive du manuscrit publié dans / Final version of the manuscript published in Global Change Biology, 2014, 20 (2), 341-51. DOI : 10.1111/gcb.12447. The original publication is available at Wiley Online library.

316 would be important evidence for the role of this bacterium in the processes leading to

317 precipitation.

$318 P$. syringae is wide-spread in habitats associated with the cycle of fresh water, from clouds to 319 precipitation to snow pack, alpine prairies and litter, lakes, rivers, epilithon, and a range of wild 320 plants as well as crops (Morris et al., 2008, 2010; Monteil et al., 2012). Its populations generally 321 consist of a mixture of lines of cells of different genotypes and phenotypes, some of which are 322 INA and others not. However, out of all sources of this bacterium studied, it is only in snowfall 323 a form of precipitation that is always initiated by freezing - that all of the strains are markedly 324 INA at warm temperatures $\left(\geq-6^{\circ} \mathrm{C}\right)$ (Morris et al., 2008). Furthermore, INA strains of $P$. syringae constitute from $60 \%$ to $100 \%$ of the populations of this bacterium that fall with rain (Morris et al., 2013b). These observations reveal a clear enrichment of ice nucleation activity when compared to the populations in cloud water for which fewer than $10 \%$ of strains of this bacterium are INA (Joly et al., 2013). It should be noted that the regular presence of $P$. syringae in rain is not likely the result of scrubbing of aerosols below clouds because this process is very were distinct from those on the plant canopy indicating that the strains in precipitation came from a source other than the local plant canopy (Constantinidou et al., 1990). It has been proposed that, by falling with precipitation, the bacterium avoids a long residence time in the atmosphere that could lead to death from desiccation or over-exposure to UV (Morris et al., 2013b). Ice nucleation activity in $P$. syringae is significantly correlated with various other traits allowing it to grow readily in a wide range of environments (Morris et al., 2010). This capacity would be necessary for a bacterium that is deposited with precipitation into diverse habitats. 
Version définitive du manuscrit publié dans / Final version of the manuscript published in Global Change Biology, 2014, 20 (2), 341-51. DOI : 10.1111/gcb.12447. The original publication is available at Wiley Online library.

340 Interestingly, other species of microorganisms whose life cycle depends critically on air-borne

341 dissemination and deposition via rainfall, obligate parasitic rust fungi such as Puccinia spp. and

342 Hemileia vastratrix, have recently been shown to be highly INA (Morris et al., 2012). Dry

343 deposition of rust spores rarely occurs once the spores have been transported up to several

344 hundred meters. Fallout from the atmosphere is assured by rainfall (Nagarajan \& Singh, 1990).

345 In contrast, none of the microorganisms that are dominant in the atmosphere have been shown to

346 be ice nucleation active at temperatures $>-10^{\circ} \mathrm{C}$ (Mortazavi et al., 2008; Bowers et al., 2009;

347 Iannone et al., 2011). These observations are strong arguments for the positive selection of

348 precipitation on ice nucleation activity of certain microorganisms. The ensemble of processes that

349 are forces for positive natural selection of microbial ice nucleation activity contribute to the

350 capacity of these microorganisms to participate in a bioprecipitation feedback cycle. If processes

351 other than precipitation are the main forces for positive selection of ice nucleation activity, then

352 environmental changes that markedly affect these processes could alter the availability of

353 microbial ice nuclei and subsequently the bioprecipitation cycle.

\section{Landscapes, aerosols and phenomena coherent with bioprecipitation}

Earth's land masses are the primary source of microbial aerosols in the atmosphere. Based on a

broad literature survey and numerical simulations using a global climate model, the average rates are consistent with simulated and observed atmospheric number concentrations of bacteria- 
Version définitive du manuscrit publié dans / Final version of the manuscript published in Global Change Biology, 2014, 20 (2), 341-51. DOI : 10.1111/gcb.12447. The original publication is available at Wiley Online library.

362 of magnitude (Elbert et al., 2007; Sesartic \& Dallafior, 2011; Huffman et al., 2012; Despres et

363 al., 2013). Vegetation is implicated as the main source of air-borne microorganisms, and more so

364 than bare soil (Lindemann et al., 1982; Lighthart, 1997; Burrows et al., 2009). In a study of the

365 composition of hailstones, the culturable bacterial community was skewed toward groups of

366 bacteria most common on plants, whereas their dissolved organic matter content was mainly from

367 soils (vs. plants) (Šantl-Temkiv et al., 2013). Overall, concentrations of bacteria and other

368 bioaerosols are generally much lower over aquatic environments than above terrestrial ones

369 (Burrows et al., 2009). Furthermore, vegetated land masses are stronger sources of biological

370 ice nuclei than water masses and non-vegetated regions (Christner et al., 2008). Likewise, clouds

371 that are warmer than $-10^{\circ} \mathrm{C}$ contain ice more frequently when they are over vegetated continental

372 regions than at coastal stations or over the open ocean (Kanitz et al., 2011) suggesting that

373 biological ice nuclei, possessing the unique capacity to catalyze ice formation at these

374 temperatures, are responsible for this ice formation.

375 The specific mechanisms involved in the emissions of microbial particles into the atmosphere

376 from their sources are mostly unknown. Some mechanisms, for example, involving active

377 emissions from dry and wet surfaces have been well documented for fungi. Active release is

378 prevalent, however, among fungi in only certain species in a limited number of phyla (Meridith,

379 1973; Elbert et al., 2007). For bacteria and also for a wide range of fungi that do not deploy

380 active release of spores, the processes of emission are linked mainly to the physical conditions

381 providing the forces for removal and release of particles. This involves energy input from an

382 external source provided by wind shear, convection, rain splash, agricultural practices such as

383 combining, etc. (Upper \& Hirano, 1991; Jones \& Harrison, 2004). Bacterial launch, in particular,

384 is most efficient during rain, when droplets shake leaves and release poorly attached particles

385 (Upper \& Hirano, 1991), or at mid-day, when leaves are dry and solar heating promotes 
Version définitive du manuscrit publié dans / Final version of the manuscript published in Global Change Biology, 2014, 20 (2), 341-51. DOI : 10.1111/gcb.12447. The original publication is available at Wiley Online library.

convection (Lindemann et al., 1982). Evidence exists for meteorological correlation between bacterial concentrations and atmospheric conditions (e.g. wind-speed and temperature) (Jones \& Harrison, 2004; Harrison et al., 2005). Although there is much that remains to be revealed about the specific mechanisms of emission, land use practices have been implicated in the rates of emission. One influential factor is the type of crop cover which not only influences the rate of emissions (Lindemann et al., 1982) but clearly influences the diversity of microorganisms that can potentially be emitted into the atmosphere. Another markedly important factor is harvesting of a crop (Lighthart, 1997) which can be responsible for the release of up to $10^{13}$ spores of the wheat rust fungus, for example, for every 5 ha of slightly diseased wheat that are harvested with a combine tractor (Friesen et al., 2001).

In light of the variability in the abundance of INA microbial populations on different plant species and in different types of vegetated ecosystems, and of the effect of land use practices on their emission, it is reasonable to suspect that the marked changes in regional precipitation patterns over the last century have been partly affected by changes in emission patterns of microbial ice nuclei resulting from drastic human-induced land use changes over this same timescale (Lioubimtseva et al., 2005; Raddatz, 2007; Pielke et al., 2007; Zeng \& Yoon, 2009; DeAngelis et al., 2010).

\section{Future scenarios: changing landscapes, changing rainfall.}

Land use changes constitute inadvertent interventions to the bioprecipitation cycle. Alterations to type, density and seasonality of vegetation cover can severely change the potential source of biological ice nucleators emitted into the atmosphere (Hirano \& Upper, 2000) and thus the patterns of cloud extent and precipitation downwind. This, in turn, must affect the net fluxes of 
Version définitive du manuscrit publié dans / Final version of the manuscript published in Global Change Biology, 2014, 20 (2), 341-51. DOI : 10.1111/gcb.12447. The original publication is available at Wiley Online library.

409

410

411

412

413

414

415

416

417

418

419

420

421

422

423

424

425

426

427

428

429

430

431

radiation entering the top of the atmosphere and reaching the ground, with possible effects on the regional climate. A shift in land use often affects soil moisture and modifies heat, moisture and momentum transfer to the atmosphere with consequences for local and regional weather (Raddatz, 2007). Large areas subjected to land use change constitute islands on a continental surface that leave an atmospheric imprint upon the more nearly uniform background surrounding them. If this imprint could be broken down into all factors causing it, the effect of biological ice nucleators may become apparent. Three examples indicate where elucidation of feedbacks involving biological ice nucleators from managed or natural landscapes could contribute to appraising their impact on regional weather and to (possibly) avoiding nefarious inadvertent consequences.

A spectacular growth during the second half of the $20^{\text {th }}$ century in irrigated areas in Central Asia has significantly increased local precipitation in large oases (Lioubimtseva et al., 2005). Similar growth in the irrigated area of the American Great Plains has, since its establishment in the early $20^{\text {th }}$ century, increased downwind precipitation during the month of July by $15-30 \%$. Only part of the additional precipitation can be explained by the increased moisture contributed by irrigation (DeAngelis et al., 2010). The addition of irrigation not only changes the type of crop cover, its density and seasonality, it also changes the emission of biological ice nucleators. Yet, the contribution of crop irrigation to altered regional precipitation patterns is unknown, and has not been the subject of much research.

There have also been land use changes over large areas on the fringes of the major deserts subjected to overgrazing, where vegetation cover is reduced, desertification progresses, albedo increases, and evaporation declines. This change leads to a feed-back loop involving a loss of water vapor from evapotranspiration, where loss of vegetation cover and reduction in 
Version définitive du manuscrit publié dans / Final version of the manuscript published in Global Change Biology, 2014, 20 (2), 341-51. DOI : 10.1111/gcb.12447. The original publication is available at Wiley Online library.

432 precipitation reinforce each other (Zeng \& Yoon, 2009). But INA microbial aerosols are also

433 potentially being lost as vegetation declines, and their loss could further accelerate desert

434 expansion.

435 A third example is the effect of urbanization on atmospheric processes. Urban areas, heat islands

436 with increased surface roughness, enhance local convection and are also significant sources of

437 aerosols. Combined, these effects result in more frequent and persistent thunderstorm activity

438 above large cities, compared to surrounding regions (Ashley et al., 2011). Recent modeling of

439 thunderstorms over São Paulo City indicates a potentially significant role of biological ice

440 nucleators in cloud development over the cityscape (Gonçalves et al., 2012). Consequently,

441 damage caused by hail or flooding could potentially be reduced by modifying the sources of

442 biological ice nucleators from a cityscape by planting, for example, trees that harbor and release

443 sufficient populations of microbial ice nucleators.

444 In all three examples, human activities have visible effects on local or regional weather regimes.

445 As anthropogenic activity and climate change further alter vegetated landscapes, increasingly

446 extreme repercussions to weather are expected. In weather processes, physical aspects are studied

447 most intensively. More recently, the role of vegetation is also being considered. Although the

448 potential of biological ice nucleators to modify cloud development has been the subject of

449 numerous investigations (e.g. Phillips et al., 2009; Gonçalves et al., 2012), we still lack the first

450 example of a study linking physical, biological and microbiological effects of human activity,

451 such as land use change, on changes in regional weather pattern. This begs for concerted

452 interdisciplinary research on this intersection between microbiology, climatology and land use

453 ecology to elucidate the extent to which microorganisms drive yet another biogeochemical cycle. 
Version définitive du manuscrit publié dans / Final version of the manuscript published in Global Change Biology, 2014, 20 (2), 341-51. DOI : 10.1111/gcb.12447. The original publication is available at Wiley Online library.

\section{References:}

Agrios GN (2005) Plant Pathology. Amstedam, Academic Press, Elsevier.

Amato P, Parazols M, Sancelme M, Laj P, Mailhot G, Delort A-M (2007) Microorganisms isolated from the water phase of tropospheric clouds at the Puy de Dôme: major groups and growth abilities at low temperatures. Fems Micriobiology Ecology, 59, 242-254.

Ansmann A, Tesche M, Althausen D, et al. (2008) Influence of Saharan dust on cloud glaciation in southern Morocco during the Saharan Mineral Dust Experiment. Journal of Geophysical Research, 113, D04210.

Ashley WS, Bentley ML, Stallins JA (2011) Urban-induced thunderstorm modification in the Southeast United States. Climatic Change, 113, 481-498.

Attard E, Yang H, Delort A-M, et al. (2012) Effects of atmospheric conditions on ice nucleation activity of Pseudomonas. Atmospheric Chemistry and Physics, 12, 10667-10677.

Bates TS, Lamb BK, Guenther A, Dignon J, Stoiber RE (1992) Sulfur emissions to the atmosphere from natural sources. Journal of Atmospheric Chemistry, 14, 315-337.

Battistuzzi FU, Feijao A, Hedges SB (2004) A genomic timescale of prokaryote evolution: insights into the origin of methanogenesis, phototrophy, and the colonization of land. BMC Evolutionary Biology, 4, 44.

Bigg EK (1958) A long period fluctuation in freezing nucleus concentrations. Journal of Meteorology, 15, 561-562.

Bower K, Moss S, Johnson D, et al. (1996) A parametrization of the ice water content observed in frontal and convective clouds. Quarterly Journal of the Royal Meteorological Society, 122, 1815-1844.

Bowers RM, Lauber CL, Wiedinmyer C, et al. (2009) Characterization of airborne microbial communities at a high-elevation site and their potential to act as atmospheric ice nuclei. Applied and Environmental Microbiology, 75, 5121-5130.

Bowers RM, McLetchie S, Knight R, Fierer N (2011) Spatial variability in airborne bacterial communities across land-use types and their relationship to the bacterial communities of potential source environments. The ISME journal, 5, 601-12.

Burrows SM, Butler T, Jöckel P, Tost H, Kerkweg A, Pöschl U, Lawrence MG (2009) Bacteria in the global atmosphere - Part 2: Modeling of emissions and transport between different ecosystems. Atmospheric Chemistry and Physics, 9, 9281-9297. 
Version définitive du manuscrit publié dans / Final version of the manuscript published in Global Change Biology, 2014, 20 (2), 341-51. DOI : 10.1111/gcb.12447. The original publication is available at Wiley Online library.

486

487

488

489

490

491

492

493

494

495

496

497

498

499

500

501

502

503

504

505

506

507

508

509

510

511

512

513

514

515

516

Christner BC, Morris CE, Foreman CM, Cai R, Sands DC (2008) Ubiquity of biological ice nucleators in snowfall. Science, 319, 1214.

Conen F, Morris CE, Leifeld J, Yakutin MV, Alewell C (2011). Biological residues define the ice nucleation properties of soil dust. Atmosphere Chemistry and Physics, 11:9643-9648 doi:10.5194/acp-11-9643-2011, 2011.

Conrad R (2009) The global methane cycle: recent advances in understanding the microbial processes involved. Environmental Microbiology Reports, 1, 285-292.

Constantinidou HA, Hirano SS, Baker LS, Upper CD (1990) Atmospheric dispersal of ice nucleation-active bacteria : the role of rain. Phytopathology, 80, 934-937.

D’Souza NA, Kawaraski Y, Gantz JD, et al. (2013) Diatom assemblages promote ice formation in large lakes. ISME Journal, 7, 1632-1640.

DeAngelis A, Dominguez F, Fan Y, Robock A, Kustu MD, Robinson D (2010) Evidence of enhanced precipitation due to irrigation over the Great Plains of the United States. Journal of Geophysical Research, 115, 1-14.

DeConto RM (2008) Plate tectonics and climate change. In: Encyclopedia of Paleoclimatology and Ancient Environments (eds: Gornitz V), pp784-797. Dordrecht, Springer-Verlag.

DeMott PJ (1990) An exploratory study of ice nucleation on soot aerosols. J. Appl. Meteorol., 29, 1072-1079.

DeMott PJ, Cziczo DJ, Prenni AJ, et al. (2003) Measurements of the concentration and composition of nuclei for cirrus formation. Proceedings of the National Academy of Sciences, 100, 14655-14660.

DeMott PJ, Möhler O, Stetzer O, et al. (2011) Resurgence in ice nuclei measurement research. Bulletin of the American Meteorological Society, 92, 1623-1635.

DeMott PJ, Prenni AJ (2010) New Directions: Need for defining the numbers and sources of biological aerosols acting as ice nuclei. Atmospheric Environment, 44, 1944-1945.

Despres VR, Huffman JA, Burrows SM, Hoose C, Safatov AS, Buryak GA, Fröhlich-Nowoisky J, Elbert W, Andreae MO, Pöschl U, and Jaenicke R (2012) Primary biological aerosol particles in the atmosphere: A review. Tellus B, 64, 15598, doi:10.3402/tellusb.v64i0.15598.

Elbert W, Taylor PE, Andreae MO, Pöschl U (2007) Contribution of fungi to primary biogenic aerosols in the atmosphere: wet and dry discharged spores, carbohydrates, and inorganic ions. Atmospheric Chemistry and Physics, 7, 4569-4588. 
Version définitive du manuscrit publié dans / Final version of the manuscript published in Global Change Biology, 2014, 20 (2), 341-51. DOI : 10.1111/gcb.12447. The original publication is available at Wiley Online library.

Fahy GM (1995) The role of nucleation in cryopreservation. In: Biological Ice Nucleation and Its Applications (eds: Lee RJ, Warren GJ, Gusta L V), pp315-336. St. Paul, MN, USA, APS Press.

Fall R, Schnell RC (1985) Association of an ice-nucleating pseudomonad with cultures of the marine dinoflagellate, Heterocapsa niei. Journal of Marine Research, 43, 257-265.

Foreman CM, Cory RM, Morris CE, et al. (2013) Microbial growth under humic-free conditions in a supraglacial stream system on the Cotton Glacier, Antarctica. Environmental Research Letters, 8, 035022 doi:10.1088/1748-9326/8/3/035022.

Freeman BC, Beattie GA (2009) Bacterial growth restriction during host resistance to Pseudomonas syringae is associated with leaf water loss and localized cessation of vascular activity in Arabidopsis thaliana. Molecular Plant Microbe Interactions, 22, 857-67.

Friesen TL, de Wolf ED, Frankl LJ (2001) Source strength of wheat pathogens during combine harvest. Aerobiologia, 17, 293-299.

Garcia E, Hill TC., Prenni AJ, DeMott PJ, Franc GD, Kreidenweis SM (2012) Biogenic ice nuclei in boundary layer air over two U.S. High Plains agricultural regions. Journal of Geophysical Research, doi:10.102.

Gonçalves FLT, Martins JA, Albrecht RI, Morales CA, Silva Dias MA, Morris CE (2012) Effect of bacterial ice nuclei on the frequency and intensity of lightning activity inferred by the BRAMS model. Atmospheric Chemistry and Physics, 13, 5677-5689.

Hahn CJ, Rossow WB, Warren SG (2001) ISCCP cloud properties associated with standard cloud types identified in individual surface observations. Journal of Climate, 14, 11-28.

Hallett J, Mossop SC (1974) Production of secondary ice particles during the riming process. Nature, 249, 26-28.

Harris-Hobbs RL, Cooper WA (1987) Field evidence supporting quantitative predictions of secondary ice production rates. Journal of Atmospheric Science, 44, 1071-1082.

Harrison RM, Jones AM, Biggins PDE, et al. (2005) Climate factors influencing bacterial count in background air samples. Int. J. Biometeorol., 49, 167-178.

Hirano SS, Baker LS, Upper CD (1996) Raindrop momentum triggers growth of leaf-associated populations of Pseudomonas syringae on field-grown snap bean plants. Applied and Environmental Microbiology, 62, 2560-2566.

Hirano SS, Upper CD (2000) Bacteria in the leaf ecosystem with emphasis on Pseudomonas syringae-a pathogen, ice nucleus, and epiphyte. Microbiology and Molecular Biology Reviews, 64, 624-653. 
Version définitive du manuscrit publié dans / Final version of the manuscript published in Global Change Biology, 2014, 20 (2), 341-51. DOI : 10.1111/gcb.12447. The original publication is available at Wiley Online library.

550

551

552

553

554

555

556

557

558

559

560

561

562

563

564

565

566

567

568

569

570

571

572

573

574

575

576

577

578

579

580

581

582

583

Hirst JM, Stedman OJ, Hogg WH (1967) Long-distance spore transport : Methods of measurement, vertical spore profiles and the detection of immigrant spores. Journal of General Microbiology, 487, 329-355.

Hoose C, Kristjánsson JE, Burrows SM (2010) How important is biological ice nucleation in clouds on a global scale? Environmental Research Letters, 5, 024009.

Huffman JA, Pöhlker C, Prenni AJ, et al. (2013) High concentrations of biological aerosol particles and ice nuclei during and after rain. Atmospheric Chemistry and Physics, 13, 17671793.

Huffman JA, Sinha B, Garland RM, et al. (2012) Size distributions and temporal variations of biological aerosol particles in the Amazon rainforest characterized by microscopy and realtime UV-APS fluorescence techniques during AMAZE-08. Atmospheric Chemistry and Physics, 12, 11997-12019.

Iannone R, Chernoff DI, Pringle A, Martin ST, Bertram AK (2011) The ice nucleation ability of one of the most abundant types of fungal spores found in the atmosphere. Atmospheric Chemistry and Physics, 11, 1191-1201.

Joly M, Attard E, Sancelme M, et al. (2013) Ice nucleation activity of bacteria isolated from cloud water. Atmospheric Environment, 70, 392-400.

Jones AM, Harrison RM (2004) The effects of meteorological factors on atmospheric bioaerosol concentrations--a review. Science of the Total Environment, 326, 151-180.

Kajava A V. (1995) Molecular modeling of the three-dimensional structure of bacterial ina proteins. In: Biological Ice Nucleation and its Applications. (eds: Lee Jr. RE, Warren GJ, Gusta L V), pp101-114. St. Paul, APS Press.

Kanitz T, Seifert P, Ansmann A, Engelmann R, Althausen D, Casiccia C, Rohwer EG (2011) Contrasting the impact of aerosols at northern and southern midlatitudes on heterogeneous ice formation. Geophys. Res. Lett., 38, 1-5.

Kasting JF, Siefert JL (2002) Life and the evolution of Earth's atmosphere. Science, 296, 10661068.

Lerat E, Daubin V, Moran NA (2003) From gene trees to organismal phylogeny in prokaryotes: the case of the gamma-Proteobacteria. PLoS Biology, 1, E19.

Lighthart B (1997) The ecology of bacteria in the alfresco atmosphere. FEMS Microbiology Ecology, 23, 263-274.

Lindemann J, Constantinidiou HA, Barchet WR, Upper CD (1982) Plants as source of airbone bacteria, including ice nucleation-active bacteria. Applied and Environmental Microbiology, 44, 1059-1063. 
Version définitive du manuscrit publié dans / Final version of the manuscript published in Global Change Biology, 2014, 20 (2), 341-51. DOI : 10.1111/gcb.12447. The original publication is available at Wiley Online library.

584

585

586

587

588

589

590

591

592

593

594

595

596

597

598

599

600

601

602

603

604

605

606

607

608

609

610

611

612

613

614

615

616
Lioubimtseva E, Cole R, Adams JM, Kapustin G (2005) Impacts of climate and land-cover changes in arid lands of Central Asia. Journal of Arid Environments, 62, 285-308.

McDonald JE (1962) Collection and washout of airborne pollens and spores by raindrops. Science, 135, 435-437.

Meridith DS (1973) Significance of spore release and dispersal mechanisms in plant disease epidemiology. Annual Review of Phytopathology, 11, 313-342.

Möhler O, Demott PJ, Vali G, Levin Z (2007) Microbiology and atmospheric processes: the role of biological particles in cloud physics. Biogeosciences, 4, 1059-1071.

Möhler O, Georgakopoulos DG, Morris CE, et al. (2008) Heterogeneous ice nucleation activity of bacteria: new laboratory experiments at simulated cloud conditions. Biogeosciences, $\mathbf{5}$, 1435-1445.

Monteil CL, Guilbaud C, Glaux C, Lafolie F, Soubeyrand S, Morris CE (2012) Emigration of the plant pathogen Pseudomonas syringae from leaf litter contributes to its population dynamics in alpine snowpack. Environmental Microbiology, 14, 2099-2112.

Morris CE, Georgakopoulos DG, Sands DC (2004) Ice nucleation active bacteria and their potential role in precipitation. Journal of Physics IV, France, 121, 87-103.

Morris CE, Leyronas C, Nicot PC (2013a) Movement of bioaerosols in the atmosphere and its consequences on climate and microbial evolution. In: Aerosol Science: Technology and Applications (eds: Colbeck, I.; Mihalis L), Hoboken, NJ, John Wiley \& Sons, in press.

Morris CE, Monteil CL, Berge O (2013b) The life history of Pseudomonas syringae: Linking agriculture to Earth system processes. Annual Review of Phytopathology, 51, 85-104.

Morris CE, Sands DC, Bardin M, et al. (2011) Microbiology and atmospheric processes: research challenges concerning the impact of airborne micro-organisms on the atmosphere and climate. Biogeosciences, 8, 17-25.

Morris CE, Sands DC, Glaux C, et al. (2012) Urediospores of rust fungi are ice nucleation active at $>-10{ }^{\circ} \mathrm{C}$ and harbor ice nucleation active bacteria. Atmospheric Chemistry and Physics, 13, 4223-4233.

Morris CE, Sands DC, Vanneste JL, Montarry J, Oakley B, Guilbaud C, Glaux C (2010) Inferring the evolutionary history of the plant pathogen Pseudomonas syringae from its biogeography in headwaters of rivers in North America, Europe and New Zealand. mBio, 1, e00107-10e00107-20.

Morris CE, Sands DC, Vinatzer BA, et al. (2008) The life history of the plant pathogen Pseudomonas syringae is linked to the water cycle. ISME Journal, 2, 321-334. 
Version définitive du manuscrit publié dans / Final version of the manuscript published in Global Change Biology, 2014, 20 (2), 341-51. DOI : 10.1111/gcb.12447. The original publication is available at Wiley Online library.

617

618

619

620

621

622

623

624

625

626

627

628

629

630

631

632

633

634

635

636

637

638

639

640

641

642

643

644

645

646

647

648

649

650

Mortazavi R, Hayes CT, Ariya PA (2008) Ice nucleation activity of bacteria isolated from snow compared with organic and inorganic substrates. Environmental Chemistry, 5, 373-381.

Mossop SC (1963) Atmospheric ice nuclei. Zeitschrift für angewandte Mathematik und Physik, 14, 456-486.

Murray BJ, Broadley SL, Wilson TW, Bull SJ, Wills RH, Christenson HK, Murray EJ (2010) Kinetics of the homogeneous freezing of water. Physical Chemistry Chemical Physics, 12, 10380-10387.

Murray BJ, Knopf DA, Bertram AK (2005) The formation of cubic ice under conditions relevant to Earth's atmosphere. Nature, 434, 202-205.

Murray BJ, O'Sullivan D, Atkinson JD, Webb ME (2012) Ice nucleation by particles immersed in supercooled cloud droplets. Chemical Society Reviews, 41, 6519-6554.

Nagarajan S, Singh DV (1990) Long-distance dispersion of rust pathogens. Annual Review of Phytopathology, 28, 139-153.

Nielsen R (2005) Molecular signatures of natural selection. (WL Montgomery, Ed.). Annual Review of Genetics, 39, 197-218.

O'Sullivan D, Murray BJ, Malkin T., Whale T, Umo NS, Atkinson, JD, Price HC, Baustian KJ, Browse J, and Webb ME (2013) Ice nucleation by soil dusts: relative importance of mineral dust and biogenic components. Atmospheric Chemistry and Physics Discussion, 13, 2027520317.

Phillips VTJ, Andronache C, Christner BC, et al. (2009) Potential impacts from biological aerosols on ensembles of continental clouds simulated numerically. Biogeosciences, 6, 1-28.

Phillips VTJ, Andronache C, Sherwood SC, et al. (2005) Anvil glaciation in a deep cumulus updraught over Florida simulated with the Explicit Microphysics Model. I: Impact of various nucleation processes. Quarterly Journal of the Royal Meteorological Society, 131, 2019-2046.

Phillips VTJ, Blyth AM, Brown PRA, Choularton TW, Latham J (2001) The glaciation of a cumulus cloud over New Mexico. Quarterly Journal of the Royal Meteorological Society, 127, 1513-1534.

Phillips VTJ, Choularton TW, Illingworth AJ, Hogan RJ, Field PR (2003) Simulations of the glaciation of a frontal mixed-phase cloud with the Explicit Microphysics Model. Quarterly Journal of the Royal Meteorological Society, 129, 1351-1371.

Phillips VTJ, DeMott PJ, Andronache C (2008) An empirical parameterization of heterogeneous ice nucleation for multiple chemical species of aerosol. Journal of the Atmospheric Sciences, 65, 2757-2783. 
Version définitive du manuscrit publié dans / Final version of the manuscript published in Global Change Biology, 2014, 20 (2), 341-51. DOI : 10.1111/gcb.12447. The original publication is available at Wiley Online library.

651

652

653

654

655

656

657

658

659

660

661

662

663

664

665

666

667

668

669

670

671

672

673

674

675

676

677

678

679

680

681

682

683

Phillips VTJ, Demott PJ, Andronache C, Pratt KA, Prather KA, Subramanian R, Twohy C (2013) Improvements to an empirical parameterization of heterogeneous ice nucleation and its comparison with observations. Journal of the Atmospheric Sciences, 70, doi: 10.1175/JASD-12-080.1.

Pielke RA, Adegoke J, Beltrán-Przekurat A, et al. (2007) An overview of regional land-use and land-cover impacts on rainfall. Tellus $B, \mathbf{5 9}, 587-601$.

Pöschl U, Martin ST, Sinha B, et al. (2010) Rainforest aerosols as biogenic nuclei of clouds and precipitation in the Amazon. Science, 329, 1513-1516.

Prenni AJ, Petters MD, Kreidenweis SM, et al. (2009) Relative roles of biogenic emissions and Saharan dust as ice nuclei in the Amazon basin. Nature Geoscience., 2, 402-405.

Prenni AJ, Tobo Y, Garcia E, et al. (2013) The impact of rain on ice nuclei populations at a forested site in Colorado. Geophysical Research Letters, 40, 227-231.

Raddatz RL (2007) Evidence for the influence of agriculture on weather and climate through the transformation and management of vegetation: Illustrated by examples from the Canadian Prairies. Agricultural and Forest Meteorology, 142, 186-202.

Reid A (2011) Incorporating microbial processes into climate models. American Academy of Microbiology, http://academy.asm.org/images/stories/documents/Incorporating_Microbial_Processes_Into_ Climate_Models.pdf

Respondek PS, Flossmann AI, Alheit RR, Pruppacher HR (1995) A theorectical study of the wet removal of atmospheric pollutants. 5. The uptake, redistribution, and depostion of (NH4)2SO4 by a convective cloud containing ice. Journal of the Atmospheric Sciences, 52, 2121-2132.

Rossow WB, Schiffer RA (1999) Advances in Understanding Clouds from ISCCP. Bulletin of the American Meteorological Society, 80, 2261-2287.

Sands DC, Langhans VE, Scharen AL, de Smet G (1982) The association between bacteria and rain and possible resultant meteorological implications. Journal of the Hungarian Meteorological Service, 86, 148-152.

Šantl-Temkiv T, Finster K, Dittman T, Hansen BM, Thyrhaug R, Nielsen NW, Karlson UG (2013) Hailstones: A window into the microbial and chemical inventory of a storm cloud. PLOS ONE, 8, e53550.

Sesartic A, Dallafior TN (2011) Global fungal spore emissions, review and synthesis of literature data. Biogeosciences, 8, 1181-1192. 
Version définitive du manuscrit publié dans / Final version of the manuscript published in Global Change Biology, 2014, 20 (2), 341-51. DOI : 10.1111/gcb.12447. The original publication is available at Wiley Online library.

684 Szyrmer W, Zawadzki I (1997) Biogenic and anthropogenic sources of ice-forming nuclei: A 685 review. Bulletin of the American Meteorological Society, 78, 209-228.

686 Tobo Y, Prenni AJ, DeMott PJ, Huffman JA, McCluskey CS, Tian G, Pöhlker C, Pöschl U, 687 688 Kreidenweis SM (2013) Biological aerosol particles as a key determinant of ice nuclei populations in a forest ecosystem, Journal of Geophysical Research. Atmospheres 118, doi:10.1002/jgrd.50801.

690 Upper CD, Hirano SS (1991) Aerial dispersal of bacteria. Biotechnology (Reading Mass.), 15, $691 \quad 75-93$.

692 Wolber PK (1993) Bacterial ice nucleation. Adv. Microb. Physiol., 34, 203-237.

693 Zachariassen KE, Kristiansen E (2000) Ice nucleation and antinucleation in nature. Cryobiology, $694 \quad 41,257-79$.

695 Zeng N, Yoon J (2009) Expansion of the world's deserts due to vegetation-albedo feedback under 696 global warming. Geophysical Research Letters, 36.

697 Zhou J, Poulsen CJ, Rosenbloom N, Shields C, Briegleb B (2012) Vegetation-climate 698 interactions in the warm mid-Cretaceous. Climate of the Past, 8, 565-576.

699 
Version définitive du manuscrit publié dans / Final version of the manuscript published in Global Change Biology, 2014, 20 (2), 341-51. DOI : 10.1111/gcb.12447. The original publication is available at Wiley Online library.

702 Acknowledgments: The authors thank the Epicurus Fund at DonorsTrust for funding to cover

703 travel for authors to meet. J. A. H. acknowledges internal faculty funding from the University of

704 Denver. V. P. acknowledges support from US Department of Energy's BER program for an

705 award supporting modeling research into aerosol impacts on glaciated clouds. C.E.M. thanks the

706 US NSF Division of Atmospheric and Geospace Sciences for funding to stimulate scientific

707 communication on the interaction of bioaerosols with atmospheric processes.

Author contributions: All authors contributed to the conception and writing of this paper. They are all aware of the full contents and give their consent to its publication.

711

\section{The authors declare no conflict of interest}



library.

\section{$714 \quad$ Figure legends}

Figure 1. Environmental phenomena contributing to the bioprecipitation cycle. There are two essential components of bioprecipitation: i) water vapor (blue lines) and ice nucleation active (INA) microorganisms (orange lines) are emitted from plants into the atmosphere where they participate in the process leading to rain and snowfall and ii) the resulting precipitation (direct rainfall or snow melt that feeds into groundwater) enhances the growth of plants and microorganisms. Plants are the major source of INA microorganisms in the atmosphere. This is reflected in the greater abundance of ice nuclei active at temperatures $>-10^{\circ} \mathrm{C}$, typical of microbial ice nuclei, over vegetated land masses than over oceans and is coherent with phenomena involved in the bioprecipitation cycle. Ice nucleation activity of microorganisms is positively selected in various ecosystems and environmental contexts (dotted lines) including aquatic habitats where freezing occurs, on frost damaged plants and with precipitation itself.

These phenomena ensure the positive evolution of ice nucleation activity in certain microorganisms and provide a favorable context for bioprecipitation.

Figure 2. Evolution of ice nucleation active (INA) bacteria in the timeline of Earth's history. The bacterial ice nucleation protein originated from a common ancestor of the $\gamma$-Proteobacteria, a class of bacteria that emerged about 1.75 billion years ago (Gya). This group of bacteria witnessed about 250 million years of glaciation (blue periods in the temperature bar) before the colonization of land by higher plants. Ice nucleation activity was advantageous most probably due to the latent heat released during freezing thereby enhancing survival in cold aquatic habitats before landmasses were inhabitable. After their association with land plants, INA bacteria were 
Version définitive du manuscrit publié dans / Final version of the manuscript published in Global Change Biology, 2014, 20 (2), 341-51. DOI : 10.1111/gcb.12447. The original publication is available at Wiley Online library.

737 readily swept up into the atmosphere and into clouds. The cycle of aerosols of INA bacteria from

738 modern landscapes being washed back to Earth's surface with precipitation represents a process

739 that has been occurring since at least the time of instauration of modern atmospheric circulation

740 patterns and cloud formation (about 100 million years) and is facilitated by a protein with several

741 hundred million more years of history of interaction with ice.

742 


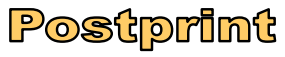

Version définitive du manuscrit publié dans / Final version of the manuscript published in Global Change Biology, 2014, 20 (2), 341-51. DOI : 10.1111/gcb.12447. The original publication is available at Wiley Online library.

743

744

745

746

747

748

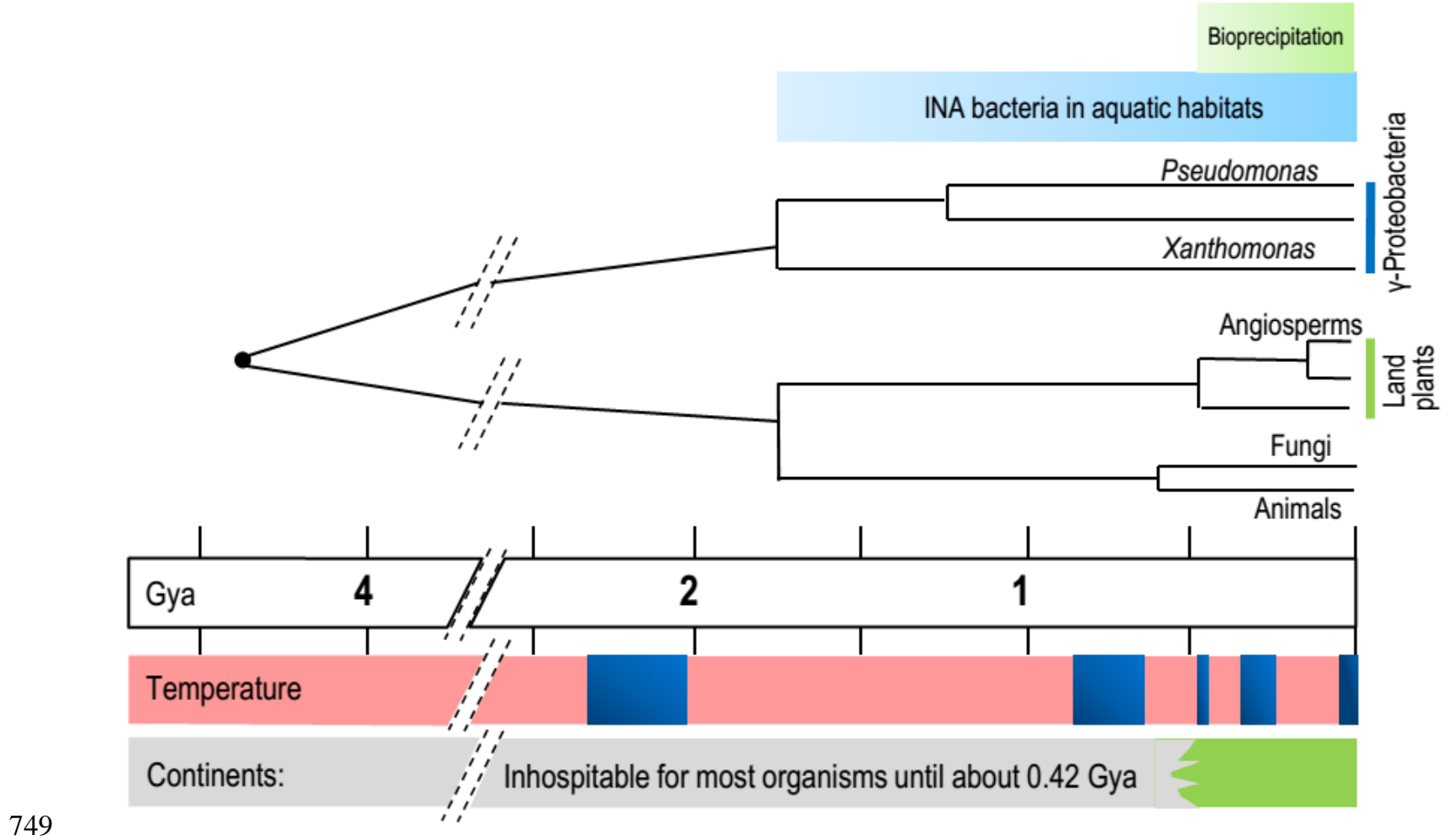

Figure 1.



Figure 2. 